\title{
Winter distribution and migration of the sound scattering layers, zooplankton and micronekton in Masfjorden, western Norway
}

\author{
Beatriz M. Baliño*, Dag L. Aksnes \\ Department of Fisheries and Marine Biology, University of Bergen, Bergen High Technology Center, N-5020 Bergen, Norway
}

\begin{abstract}
Sound scattering layers (SSLs) and vertical distribution of zooplankton and micronekton in Masfjorden, western Norway, were studied in January 1988. Two characteristic SSLs were found in the deepest fjord basin (bottom depth $490 \mathrm{~m}$ ) while single scattering layers were observed in shallower basins (depths $<300 \mathrm{~m}$ ). The SSLs performed diurnal vertical displacements, exhibiting migrational speeds of up to $90 \mathrm{~m} \mathrm{~h}^{-1}$ The adjustment of the SSLs' day depth was directly proportional to the rate of change in the logarithm of surface light and inversely proportional to the extinction coefficient of the water. Large horizontal differences in biomass in the fjord are related to a combination of advection and changes in migrational behaviour. Feeding activity of the micronekton was higher during light hours. Euphausiids of the deepest basin were mainly feeding on detritus while those in the innermost part of the fjord seemed to be preying upon copepods. The observed vertical distribution of the zooplankton and micronekton were examined in relation to mode of feeding (visual vs tactile), trophic level (omnivory vs carnivory), size (small vs large), and food type and availability
\end{abstract}

KEY WORDS: Fjord · Light · Micronekton - Migration - Sound scattering layers (SSLs) - Zooplankton

\section{INTRODUCTION}

Sound scattenng layers (SSLs) are common in Norwegian fjords (Hopkins \& Evans 1979, Evans \& Hopkins 1981, Falk-Petersen \& Hopkins 1981, Falk-Petersen \& Kristensen 1985, Reppe 1986). Vertical movements of SSLs are important when trying to understand the observed diel differences in acoustic patterns (Farquhar 1977). Their distribution and vertical migrations are of considerable ecological significance as the main constituents, the fishes and the major zooplankton groups, occupy adjacent links in the food chain. Distinctive SSLs were recorded all along the fjord axis using a $120 \mathrm{kHz}$ echosounder during surveys in Masfjorden in 1986 and 1987; a subsequent cruise was carried out in January 1988 to (1) describe the diurnal variations in depth distributions of the SSLs including calculations of migra-

\footnotetext{
- Present address: IBM Bergen Environmental Sciences \& Solutions Centre, Thormøhlensgate 55, N-5008 Bergen, Norway
}

tional velocities; (2) evaluate the role of light as the initiating cue for the vertical displacements; and (3) establish the horizontal and diel vertical distributions in the species composition and biomass of the zooplankton and micronekton communities. The vertical distributions are discussed with respect to mode of feeding, trophic level, size of the organism, and type and availability of food.

\section{MATERIAL AND METHODS}

Study area. Masfjorden (Fig. 1) is located on the west coast of Norway approximately $50 \mathrm{~km}$ north of Bergen. It is an arm of the larger Fensfjord, from which it is separated by a $75 \mathrm{~m}$ deep sill. Masfjord is approximately $20 \mathrm{~km}$ long with an average width of $1 \mathrm{~km}$ and a maximum depth of $494 \mathrm{~m}$. The study was carried out from 22 to 26 January 1988. Acoustic recordings were effected all along the fjord axis while sampling occurred mainly in the deepest basin (Stn B) and at the head of the fjord (Stn D) (Fig. 1). 

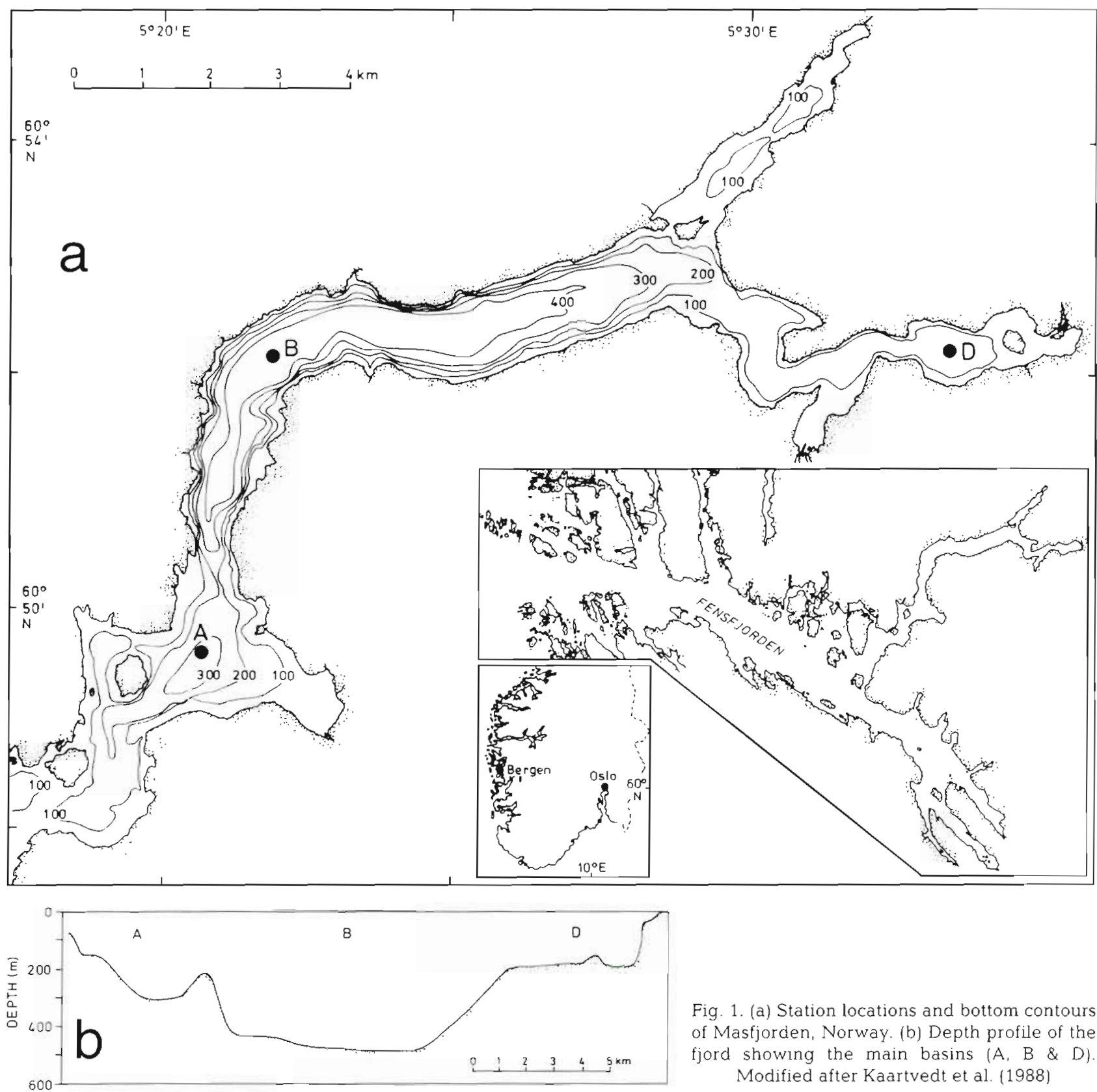

Fig. 1. (a) Station locations and bottom contours of Masfjorden, Norway. (b) Depth profile of the fjord showing the main basins (A, B \& D). Modified after Kaartvedt et al. (1988)

Hydrography, light and acoustical investigations. At $\operatorname{Stn} B$, temperature and salinity were measured on 22 January with a. Neil Brown CTD. The readings from the first $10 \mathrm{~m}$ were not properly recorded and are not included. At Stn D, profiles of temperature and salinity were obtained with the MOCNESS sensors. Surface light was measured continuously on 3 consecutive days, with an LI-185 photometer (Lambda Instruments Corp.). The light extinction coefficient was estimated from underwater light measurements in the upper $60 \mathrm{~m}$ with a QSP-160 quantum sensor on 2 consecutive days. A $120 \mathrm{kHz}$ echosounder (Simrad EK 120A) was recording continously to investigate the acoustic scattering layers. The SSLs' migrational velocities were estimated from the echosounder's printouts by measuring the depth location of the layers' upper borders at 10 to $30 \mathrm{~min}$ intervals. Concurrent light intensities at the top of the layers were calculated from surface light and the estimated light extinction coefficient.

Biological sampling and analyses. Water samples for measurements of chlorophyll $a$, carbon and nitrogen were taken at Stn B on 22 and 23 January with a rosette of Niskin bottles. The following depths were sampled: $1,5,20,30,50,70,100,160,250$ and $350 \mathrm{~m}$. 
Samples (100 ml each) were filtered through a $0.45 \mathrm{~mm}$ filter for chlorophyll a measurements. The filters were frozen and analyzed according to Holm-Hansen et al. (1965). For carbon and nitrogen content of the organic matter, 0.50 to 0.751 were filtered and analyzed with a Carlo Erba Strumentatione $1106 \mathrm{CHN}$-analyzer.

Samples of zooplankton and micronekton were obtained by a $1 \mathrm{~m}^{2}$ MOCNESS (Wiebe et al. 1985) equipped with 8 nets of $330 \mu \mathrm{m}$ mesh size and towed at 2 knots. A total of 6 hauls were carried out at Stn B: 2 during the day (on 24 January at 10:22 and 14:16 h) and 4 during the night (on 22 January at $21: 00 \mathrm{~h}_{\text {; }}$ 23 January at 00:37 and 23:00 $\mathrm{h}_{\text {; }}$ and 25 January at 02:00 h). At Stn D, only a single haul on the night of 25 January at 05:00 h was carried out. On board, the micronekton (fishes and shrimps) and macroplankton (euphausiids) were separated from the mesozooplankton (rest) by means of a $4 \mathrm{~mm}$ sieve. Micronekton and macroplankton were sorted by groups and frozen for later biomass analysis. The mesozooplankton was split with a Motoda splitter (Motoda 1954). One subsample was frozen for biomass analysis and the other fixed in $4 \%$ buffered formaldehyde for species analysis and enumeration. In the laboratory, biomass samples were dried to a constant weight at $60^{\circ} \mathrm{C}$ for a mininum of $24 \mathrm{~h}$ and ashed at $480^{\circ} \mathrm{C}$ for $3 \mathrm{~h}$. Ash-free dry weight was used as the primary measure of biomass. Mesozooplankton identification and counting were done with a binocular microscope on subsamples obtained from a Motoda splitter and/or a Lea-Wiborg plankton divider (Wiborg 1951).

Macroplankton and micronekton for analysis of stomach contents were sampled with an Isaac Kidd Midwater Trawl (IKMT). The IKMT had $2 \mathrm{~mm}$ mesh size, a mouth aperture of $0.67 \mathrm{~m}^{2}$ and was towed obliquely with a speed of 4 knots. For details of the methodology of the IKMT sampling, see Kaartvedt et al. (1988). The samples were preserved in $4 \%$ formaldehyde. The fish were also given an injection of formaldehyde in the stomach cavity to stop digestion. In the laboratory, standard length of fish and total length of shrimp and euphausiids (from the anterior margin of the eye to the tip of the telson) were measured. The stomach contents were examined under a binocular microscope and the degree of filling was classified as empty, little to half full, and full.

The sampling schedule is given in Table 1.

\section{RESULTS}

\section{The environment}

Temperature and salinity profiles at Stns B \& D were similar, clearly showing the influence of the sill, i.e. surface waters with marked temperature and salinity gradients lying over a homogeneous water column below sill depth (Fig. 2).

Fig. 3a shows the diel variation of incident radiation from 22 to 24 January. Large variations on 23 January were due to variable cloudiness. Underwater light and

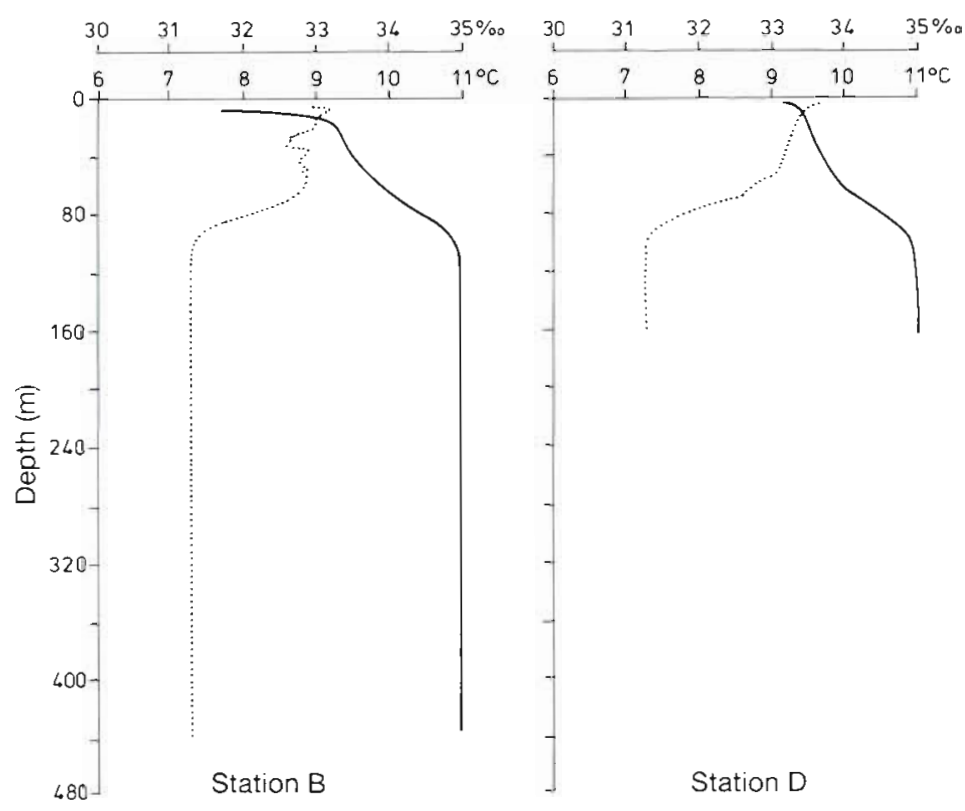

Fig. 2. Temperature (‥) and salinity (-) profiles at Stns B \& D

Table 1. Acoustic and biological sampling in Masfjorden, Norway

\begin{tabular}{|lcrll|}
\hline Device & Stn & Date & Sampling time & \multicolumn{1}{c|}{ Sampling depths (m) } \\
\hline 120 kHz sounder & A, B, D & $22-25$ Jan & Continuously & $0-300$ (Stn A), 0-400 (Stn B), 0-200 (Stn D) \\
MOCNESS & B & $22-25$ Jan & Day/night & $0-20,20-40,40-60,60-80,80-120,120-200,200-300,300-400$ \\
& D & 25 Jan & Night & $0-20,20-40,40-60,60-80,80-100,100-120,120-140,140-160$ \\
IKMT & B & 25-26 Jan & Day/night & $0-300$ \\
\hline
\end{tabular}




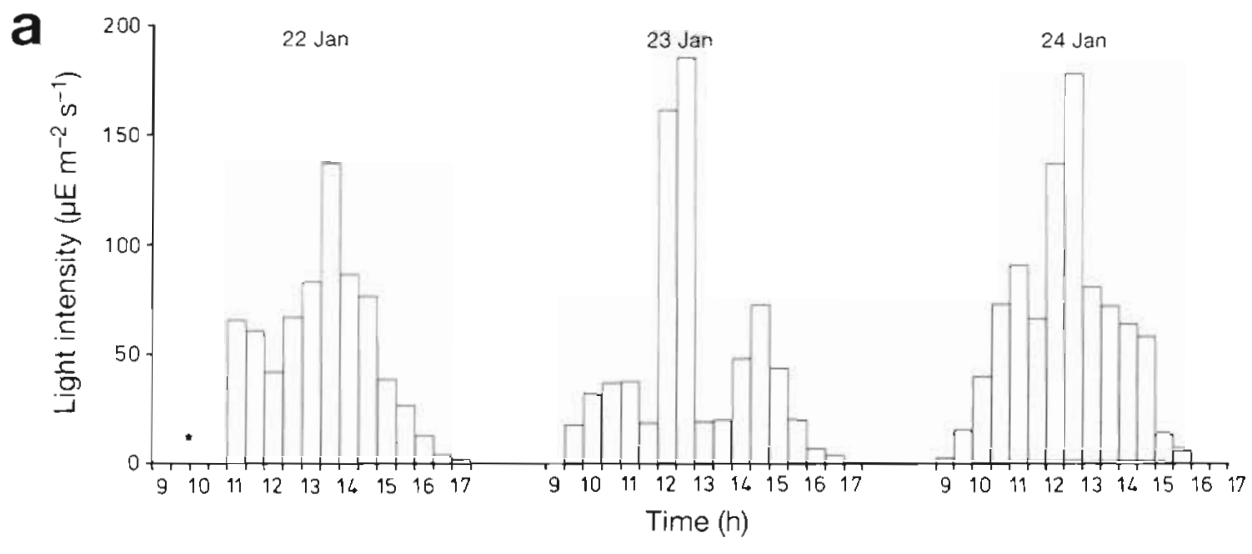

b

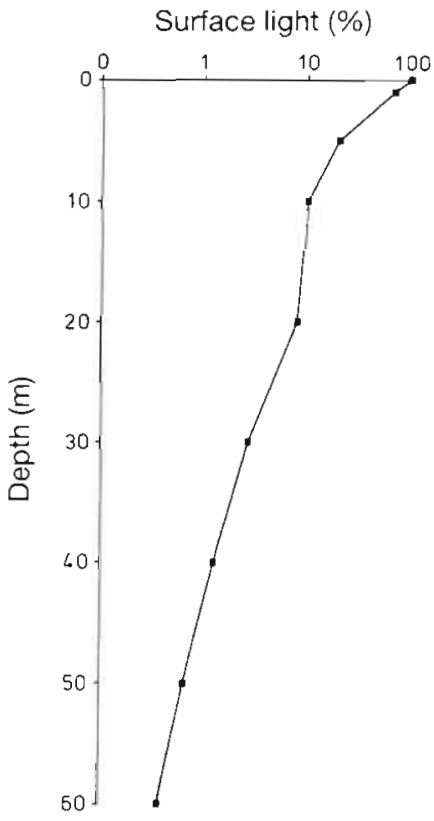

Extinction coefficient $\left(\mathrm{m}^{-1}\right)$

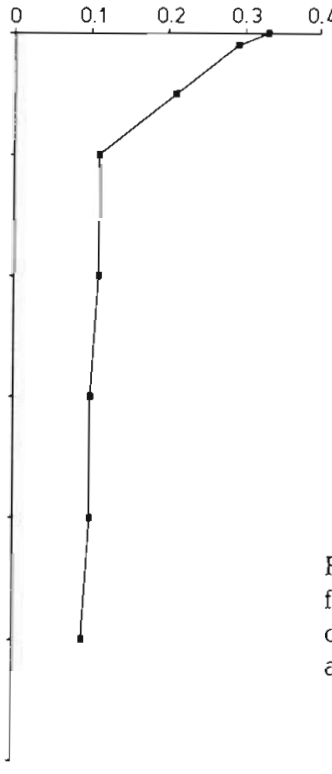

Fig. 3. (a) Surface light in Masfjorden from 22 to 24 January 1988. (b) Percentage of surface light with depth and light extinction coefficient. ( $\star$ ) no measurements

light extinction coefficients in the upper $60 \mathrm{~m}$ show a sharp decrease in the first $10 \mathrm{~m}$, followed by a relatively constant, exponential light reduction with depth (Fig. 3b).

Chlorophyll a concentrations were low at all depths (<0.1 $\mathrm{mg} \mathrm{m}^{-3}$ ) (Fig. 4a). The particulate organic carbon (POC) varied between 100 and $150 \mathrm{mg} \mathrm{m}^{-3}$, except for a maximum of $200 \mathrm{mg} \mathrm{m}^{-3}$ at $100 \mathrm{~m}$ depth (Fig. $4 \mathrm{~b}$ ). The C:N weight ratio showed an overall decrease with depth from $13(5 \mathrm{~m})$ to $8(350 \mathrm{~m})$ (Fig. $4 \mathrm{c})$.

\section{Sound scattering layers (SSLs) in Masfjorden}

\section{Station B}

Two distinct SSLs were recorded in the upper $200 \mathrm{~m}$ at Stn B (Fig. 5). Both layers (here referred to as I and II, top and bottom layers respectively) were com-

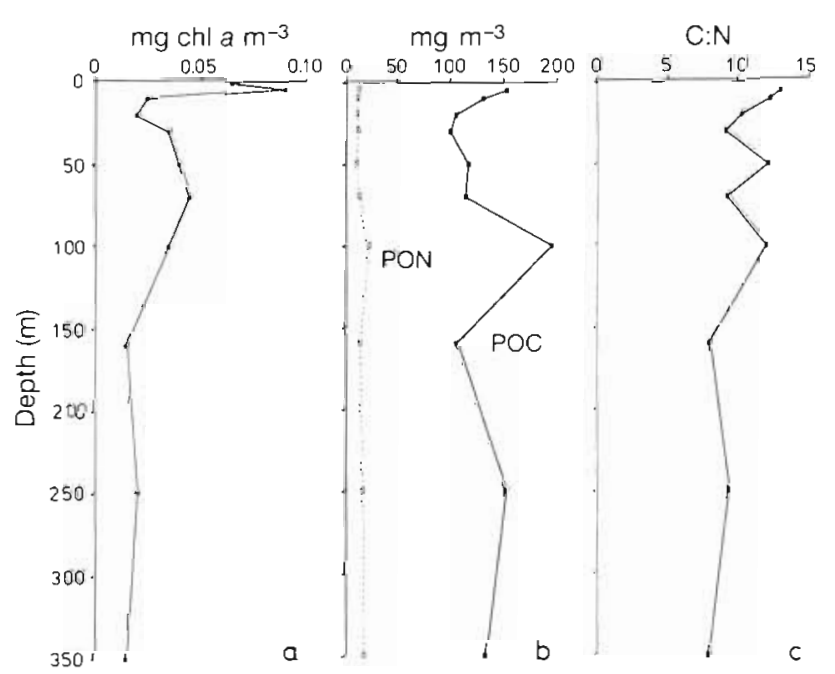

Fig. 4. Vertical profiles of (a) chlorophyll $a_{1}$ (b) particulate organic carbon (POC) and nitrogen (PON), and (c) $C: N$ weight ratio of the organic matter 

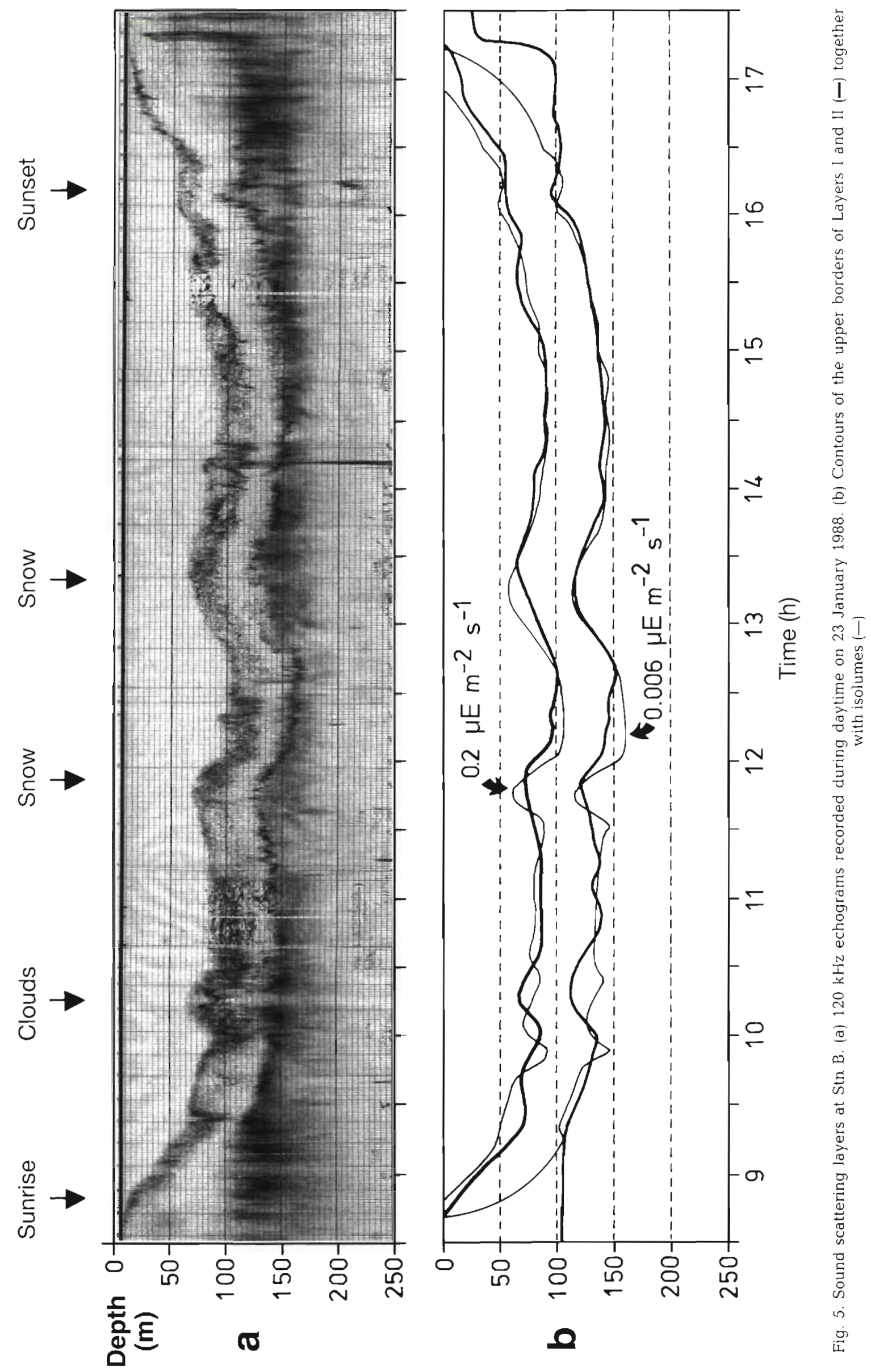

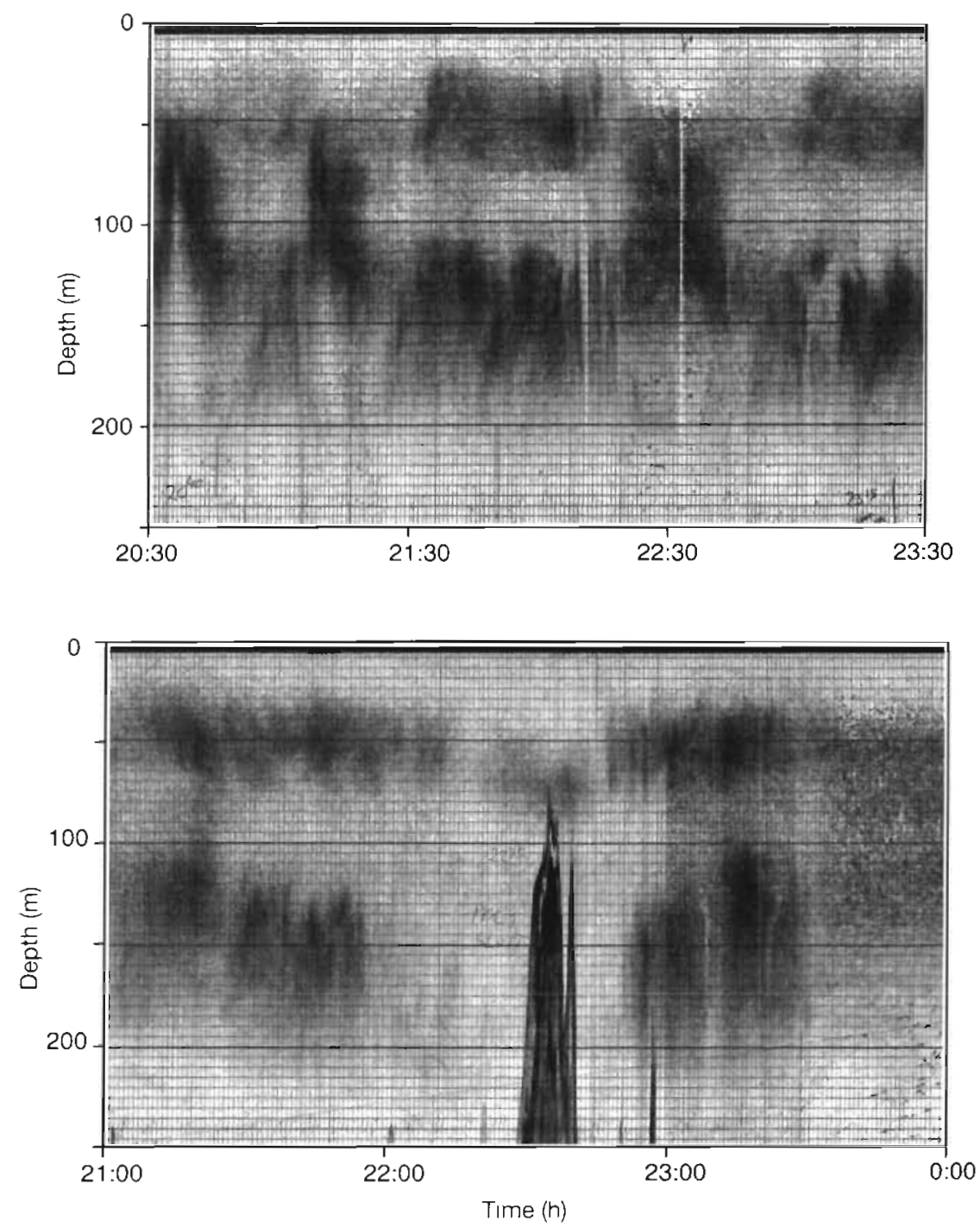

Fig. 6. Stn B. Acoustic recordings on 22 January (lower echogram) and 23 January (upper echogram) at night

pact during daytume and broad at night, sometimes converging into a single layer during darkness (Fig. 6, upper echogram).

The day-depth of Layer I oscillated between 60 and $140 \mathrm{~m}$, depending on prevalling surface light (Fig. 5). It showed consistent vertical migration throughout the study. It became narrower in its upward displacement at dusk and by the time it reached the surface, it vanished from the echograms, indicatung an aggregation in the upper $5 \mathrm{~m}$ not recorded by the echosounder. After sunset, the layer reappeared in the echograms and spread around its night depth $(50 \mathrm{~m})$ In the morning, before light could be detected $\left(<0.01 \mu \mathrm{E} \mathrm{m}^{-2} \mathrm{~s}^{-1}\right)$, this layer exhibited a pre-dawn nse, previous to the start of its downward displacement (Fig 7). The migrational velocity exhibited by this layer ranged from -80 to $+90 \mathrm{~m} \mathrm{~h}^{-1}$ (negative values indicate upward displacement).
Unlike Layer I, Layer II did not react as an unit to changes in surface light (Fig. 5). The upper border of Layer II adjusted its depth location according to light fluctuations, while the lower border varied slightly or not at all. Thus, the center of the layer remained roughly at the same depth during day hours $(150 \mathrm{~m})$,

Table 2 Regression equations $(y=b x+a)$ describing the relatronship between the layers' migrational velocity $\left(\mathrm{m} \mathrm{h}^{-1}\right)$ and the loganthm of the rate of change in surface light $\left(\mathrm{h}^{-1}\right)$ for Layers I, II and both data sets combined. $\mathrm{R}^{2}$ : coefficient of determunation; p probability level; n: no. of observations

\begin{tabular}{|lrrccc|} 
& $b$ & $a$ & $\mathrm{R}^{2}$ & $\mathrm{p}$ & $\mathrm{n}$ \\
\hline Layer I & 1111 & -1.61 & 0.71 & $<0.001$ & 45 \\
Layer II & 953 & 0.41 & 0.66 & $<0.001$ & 45 \\
Layer I + II & 10.36 & -0.60 & 0.68 & $<0.001$ & 90 \\
\hline
\end{tabular}




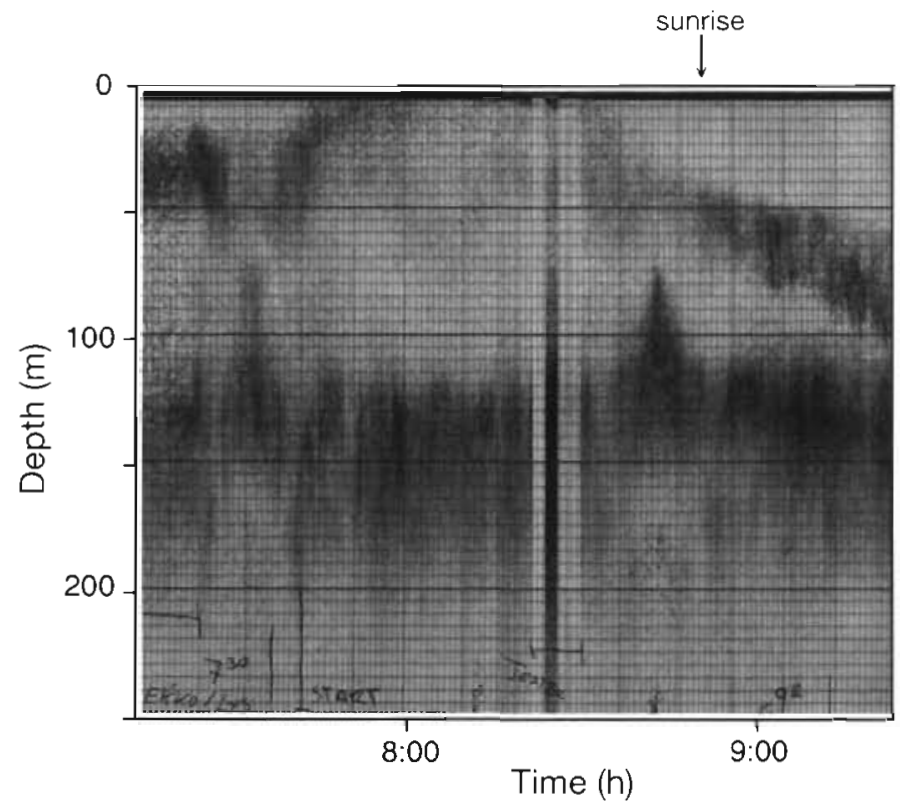

Fig. 7. Stn B. Acoustic recordings on 24 January at dawn

and the reaction to light was more like a change in thickness rather than a true displacement. Migrational velocities were estimated to $\pm 60 \mathrm{~m} \mathrm{~h}^{-1}$, and the vertical distance travelled was ca $50 \mathrm{~m}$. By day, the thickness of Layer II was ca 50 to $60 \mathrm{~m}$ and by night ca $100 \mathrm{~m}$. Layer II vanished in the vicinity of bottom ridges (Fig. 6 , lower echogram).

The depth distribution of the upper borders of the SSLs were highly influenced by variations in light. The upper part of Layer I oscillated around the $0.20 \mu \mathrm{E} \mathrm{m}^{-2} \mathrm{~s}^{-1}$ isolume on 23 January (Fig. 5b) and 24 January while it followed the $0.33 \mu \mathrm{E} \mathrm{m} \mathrm{m}^{-2} \mathrm{~s}^{-1}$ isolume on 22 January. The upper border of Layer II followed closely the $0.006 \mu \mathrm{E} \mathrm{m}^{-2} \mathrm{~s}^{-1}$ isolume all days. The logarithm of the rate of change in surface light $\left(x=\Delta \ln I_{0} / \Delta t\right)$ and the migrational speed $(y=\Delta z / \Delta t)$ for each layer was significantly positively correlated (Table 2).

\section{Stations A \& D}

At Stns A \& D, only a single scattering layer was observed during the night.

At Stn $A$, the bottom of the layer was at 70 to $80 \mathrm{~m}$ depth. This layer showed varying thickness, the spreading always occurring towards the surface (Fig. 8). Diffuse scattering was seen below this layer although it did not constitute a definite scattering layer.
At Stn D, a thick and dense layer was observed at the depth interval 50 to $150 \mathrm{~m}$ (Fig. 9). On 25 January, after sunrise, this layer migrated towards the bottom (130 to $150 \mathrm{~m}$ )

Acoustic recordings carried out along the fjord axis at night on 24 January are shown in Fig. 10 It can be seen that the layer at Stn $A$ and Layer I at Stn B are the same, while Layer II formed once the boat entered the deepest basin (B). On the other hand, it is not clear whether both layers 'join' into one in the passage from Stn B to Stn D or the single layer at Stn D is actually a separated entity from those in the deepest basin.

\section{Mesozooplankton: composition, abundance and vertical distributions}

Copepods were numerically dominant, contributing up to $91 \%$ of the total mesozooplankton (Table 3), Copepodite V (CV) of Calanus finmarchicus made up the bulk of the copepod biomass at all stations sampled. The noncopepod plankton was composed mainly of gelatinous organisms (Lensia sp. and Aglantha sp.), ostracods, bryozoan larvae (cyphonautes), chaetognaths (Sagitta elegans Verril, Eukronia hamata Mobius and E. bathypelagica Alvarino and the pelagic polychaete Tomopteris sp.

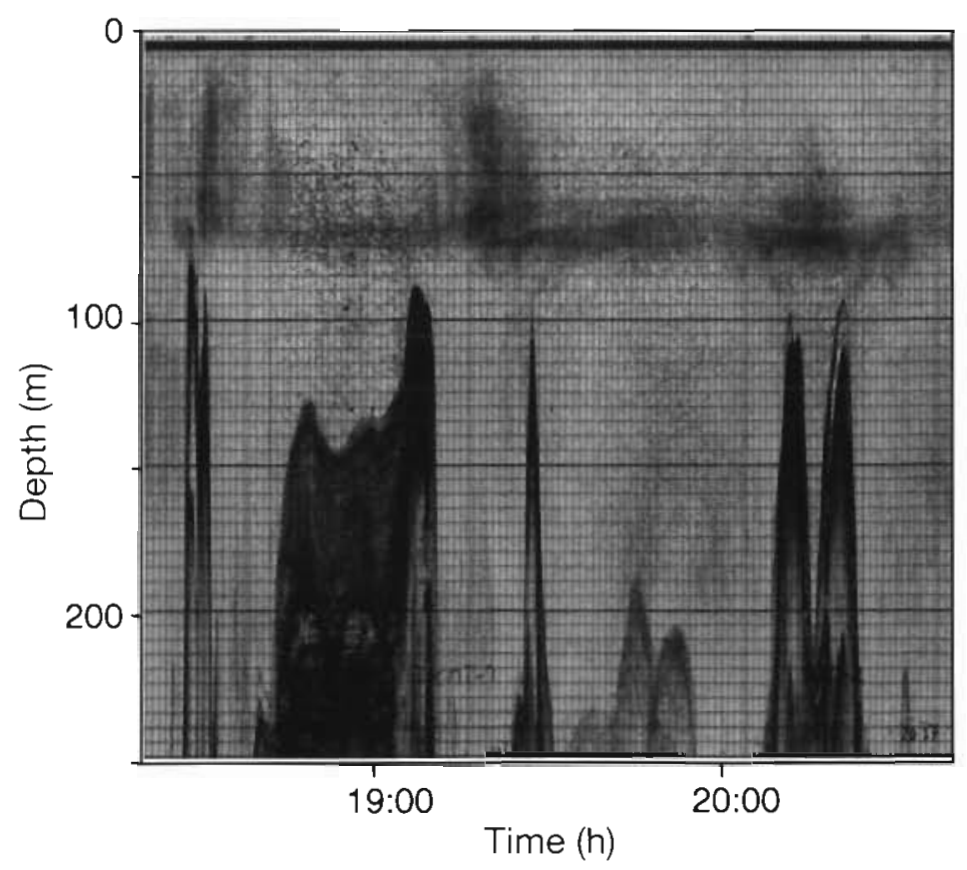

Fig. 8. Stn A. Acoustic recordings on 24 January at night 

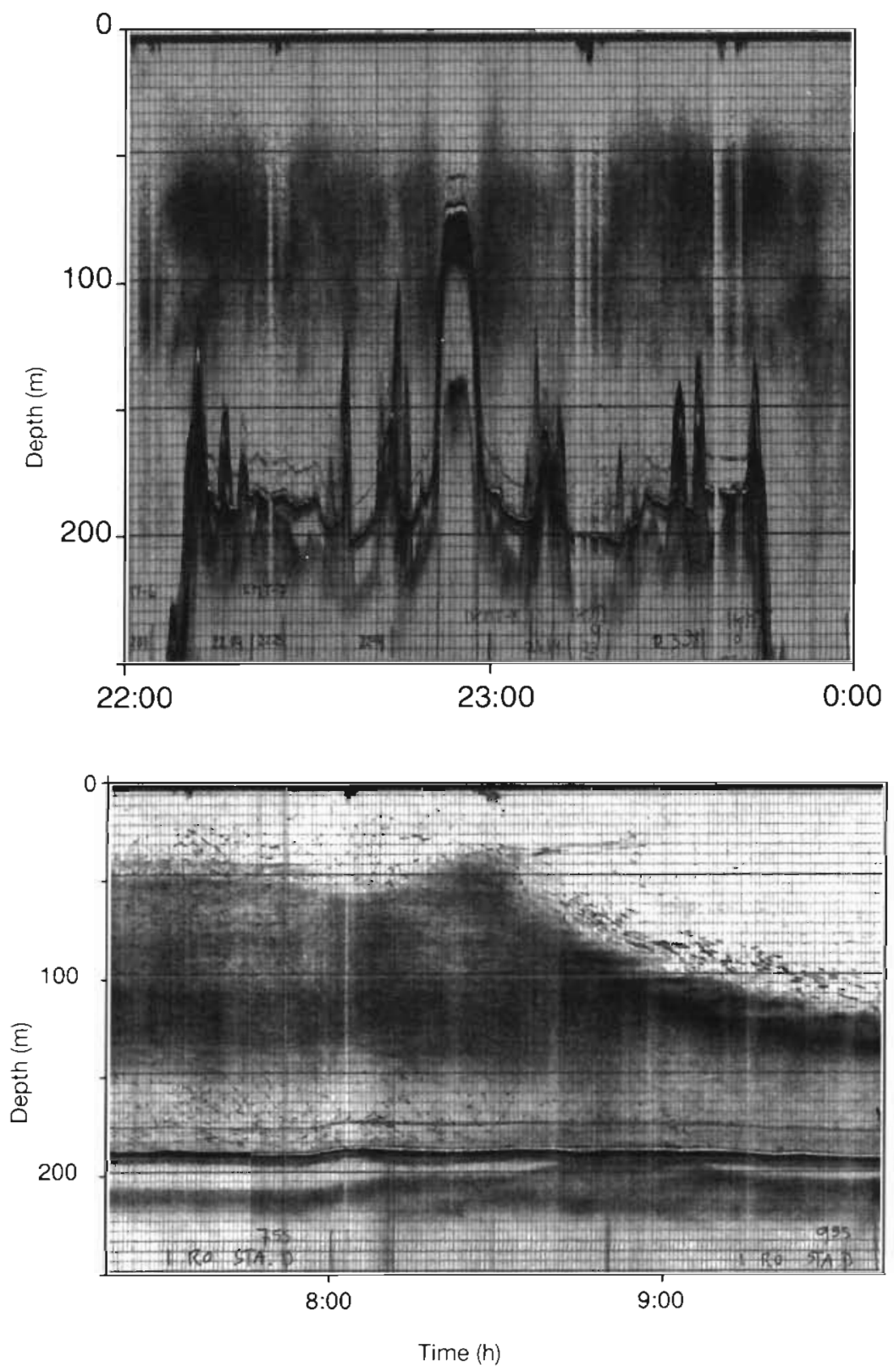

Fig. 9. Stn D. Acoustic recordings on 24 January (upper echogram) and 25 January (lower echogram) at night

\section{Station B}

Calanus finmarchicus was spread throughout the water column, but was highly concentrated between 120 and $300 \mathrm{~m}$ (Fig. 11a). Individuals from shallow waters exhibited markedly different body characteristics from those at depth. The former, mainly concentrated in the upper $60 \mathrm{~m}$, were small and translucent. The 'deep' population, however, showed overwintering features (large, pigmented individuals with fat reserves). Diel differences in distribution could not be detected.
Copepodites and adults of Metridia longa and $M$. lucens ranked second in abundance ( 5 to $6 \%$ of the total). Adult $M$. longa inhabited deep waters both day and night. Adult $M$. lucens were mainly found between 200 and $300 \mathrm{~m}$ during the day, while the distribution was bimodal at night when females, in particular ascended to shallow waters (Fig. 11b). The bulk of copepodites remained in deep waters during light hours and spread through the water column at night.

Other copepods were present in very low numbers. Acartia spp. (only females) were located in surface waters, concentrating in the upper $20 \mathrm{~m}$ (Fig. 11c). Oithona spp. (only adults stages) were distributed throughout the water column, but more concentrated in the 80 to $200 \mathrm{~m}$ strata (Fig. 11c). Copepodites and females of Candacia armata were always in deep waters $(>300 \mathrm{~m})$. None of these species showed diel migrations (Fig. 11c).

Adults of Pseudocalanus elongatus Boeck were spread throughout the water column while the copepodites were more abundant in deep waters (Fig. 11c). All stages of the carnivores Chiridius armatus (Boeck) and Euchaeta norvegica Boeck were typically in deep waters during light hours (below $120 \mathrm{~m}$ depth) (Fig. 11d). At night, $C$. armatus was distributed in the entire water column while only the copepodites of E. norvegica migrated towards surface waters.

The gelatinous plankton exhibited a constant diel depth distribution: Lensia sp. spread throughout the water column while Aglantha sp. was found more abundant at depths below $200 \mathrm{~m}$ (Table 3). The rest of the zooplankton were found at all depths but being slightly more abundant in deep waters

\section{Station D}

The numerical abundance of the mesozooplankton was at least an order of magnitude lower at Stn D than at Stn B (Table 3). Copepods, primarily Calanus finmarchicus, also prevailed at this station, being more abundant in the 120 to $160 \mathrm{~m}$ stratum (maximum depth: $200 \mathrm{~m}$ ). Copepodites and adults of Metridia spp. 
Table 3. Mesozooplankton. Species composition, vertical distribution and abundance integrated for the whole water column at $\operatorname{Stn} B$ (average of 2 day hauls and 4 night hauls), and at night at Stn D (single haul)

\begin{tabular}{|c|c|c|c|c|c|c|c|c|c|}
\hline \multicolumn{4}{|l|}{ Group/species } & \multicolumn{4}{|c|}{ Abundance (ind $\mathrm{m}^{-3}$ ) } & \multirow[b]{2}{*}{$300-400$} & \multirow[b]{2}{*}{$0-400$} \\
\hline Depth interval $(m)$ : & $0-20$ & $20-40$ & $40-60$ & $60-80$ & $80-120$ & $120-200$ & $200-300$ & & \\
\hline Day & & & & Stn B & & & & & \\
\hline \multicolumn{10}{|l|}{ Copepods } \\
\hline Calanus finmarchicus & 12.8 & 5.5 & 0.9 & 5.3 & 1.5 & 322.3 & 111.8 & 14.2 & 97.3 \\
\hline Rest & 4.1 & 0.8 & 0.6 & 1.0 & 4.9 & 13.5 & 10.7 & 3.1 & 7.0 \\
\hline \multicolumn{10}{|l|}{ Gelatinous plankton } \\
\hline Lensia sp. & 0.6 & 4.6 & 1.9 & 0.7 & 0.3 & 0.4 & 1.7 & 0.9 & 1.2 \\
\hline Aglantha sp. & 0.0 & 0.0 & 0.0 & 0.1 & 0.0 & 0.1 & 1.5 & 0.6 & 0.6 \\
\hline \multicolumn{10}{|l|}{ Other } \\
\hline Chaetognatha & 0.0 & 0.0 & 0.0 & 0.1 & 0.1 & 2.1 & 1.9 & 2.7 & 1.6 \\
\hline Tomopteris sp. & 0.0 & 0.1 & 0.0 & 0.1 & 0.2 & 0.0 & 0.0 & 0.0 & 0.0 \\
\hline Ostracoda & 0.0 & 0.0 & 0.0 & 0.1 & 0.0 & 0.3 & 1.7 & 2.6 & 1.1 \\
\hline Bryozoa larvae & 4.8 & 2.1 & 1.9 & 4.9 & 6.2 & 8.3 & 5.7 & 0.3 & 4.5 \\
\hline Rest & 0.1 & 0.0 & 0.0 & 0.1 & 0.1 & 0.6 & 0.1 & 5.0 & 1.4 \\
\hline Total & 22.4 & 13.1 & 5.3 & 12.4 & 13.3 & 347.6 & 135.1 & 29.4 & 114.6 \\
\hline \multicolumn{10}{|l|}{ Night } \\
\hline \multicolumn{10}{|l|}{ Copepods } \\
\hline Calanus finmarchicus & 9.7 & 8.3 & 3.9 & 2.7 & 2.2 & 164.8 & 144.7 & 12.2 & 73.6 \\
\hline Rest & 7.4 & 2.9 & 4.0 & 4.8 & 4.0 & 6.3 & 11.5 & 2.3 & 6.0 \\
\hline \multicolumn{10}{|l|}{ Gelatinous plankton } \\
\hline Lensia sp. & 0.4 & 2.5 & 2.7 & 0.8 & 0.3 & 1.0 & 1.0 & 0.7 & 1.0 \\
\hline Aglantha sp. & 0.0 & 0.0 & 0.0 & 0.0 & 0.0 & 0.3 & 1.0 & 0.9 & 0.5 \\
\hline \multicolumn{10}{|l|}{ Other } \\
\hline Chaetognatha & 0.0 & 0.0 & 0.1 & 0.2 & 0.1 & 1.8 & 1.5 & 1.9 & 1.2 \\
\hline Tomopteris sp. & 4.2 & 0.5 & 0.2 & 0.2 & 0.1 & 0.1 & 0.1 & 0.0 & 0.3 \\
\hline Ostracoda & 0.0 & 0.0 & 0.0 & 0.0 & 0.0 & 0.3 & 1.4 & 1.0 & 0.7 \\
\hline Bryozoa larvae & 1.7 & 2.2 & 2.0 & 2.1 & 4.2 & 3.6 & 8.5 & 0.1 & 3.7 \\
\hline Rest & 0.1 & 0.1 & 0.1 & 0.1 & 0.0 & 0.1 & 0.1 & 1.4 & 0.4 \\
\hline Total & 23.5 & 16.7 & 13.0 & 11.0 & 10.7 & 178.3 & 169.8 & 20.5 & 87.5 \\
\hline Night & & & & Stn D & & & & & \\
\hline \multicolumn{10}{|l|}{ Copepods } \\
\hline Calanus finmarchicus & 4.5 & 4.7 & 0.5 & 0.6 & 0.5 & 0.4 & 9.5 & 21.1 & 5.2 \\
\hline Rest & 1.4 & 1.1 & 0.5 & 0.2 & 0.2 & 0.1 & 11.9 & 11.9 & 3.4 \\
\hline \multicolumn{10}{|l|}{ Gelatinous plankton } \\
\hline Lensia sp. & 0.1 & 0.4 & 0.0 & 0.0 & 0.0 & 0.0 & 0.0 & 0.0 & 0.1 \\
\hline Aglantha sp. & 0.0 & 0.0 & 0.0 & 0.0 & 0.0 & 0.0 & 0.0 & 0.1 & 0.0 \\
\hline \multicolumn{10}{|l|}{ Other } \\
\hline Chaetognatha & 0.0 & 0.1 & 0.0 & 0.0 & 0.0 & 0.1 & 0.0 & 0.2 & 0.1 \\
\hline Tomopteris sp. & 0.0 & 0.1 & 0.0 & 0.1 & 0.0 & 0.6 & 0.0 & 0.2 & 0.1 \\
\hline Ostracoda & 0.0 & 0.1 & 0.0 & 0.0 & 0.0 & 0.0 & 0.1 & 0.4 & 0.1 \\
\hline Bryozoa larvae & 0.7 & 0.6 & 0.2 & 0.0 & 0.0 & 0.1 & 0.6 & 0.6 & 0.4 \\
\hline Rest & 0.2 & 0.2 & 0.0 & 0.0 & 0.0 & 0.0 & 0.1 & 0.2 & 0.1 \\
\hline Total & 6.9 & 7.3 & 1.2 & 0.9 & 0.7 & 1.3 & 22.2 & 34.7 & 9.4 \\
\hline
\end{tabular}

were relatively more abundant than in the main basin ( 35 vs $6 \%$ ) although there was no difference in absolute terms.

\section{Vertical and horizontal distribution of biomass}

Fig. 12 shows the vertical distribution of zooplankton and micronekton biomass at Stns B \& D. The micronekton was composed of the mesopelagic fishes Benthosema glaciale (Reinhardt) and Maurolicus muelleri (Gmelin) and the pelagic shrimps Pasiphea multidentata Esmark and Sergestes arcticus Kroyer. The euphausiid Meganyctiphanes norvegica (M. Sars) was almost the sole component of the macrozooplankton.

At Stn B, fishes and shrimps were caught in the entire water column at night but only in the deeper 


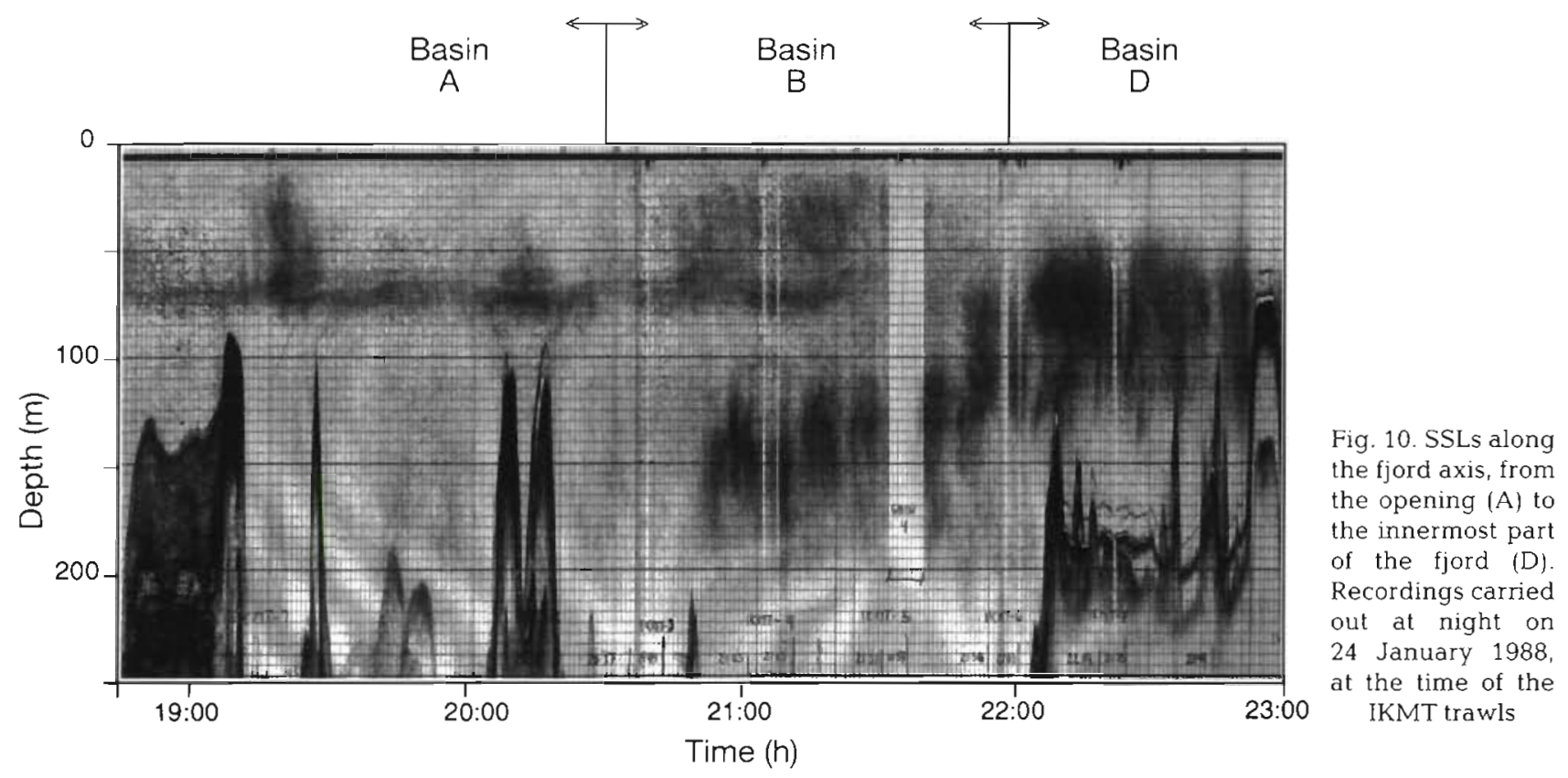

strata during the day. The euphausiid were not captured during daytime while at night, they were found concentrated in the upper $20 \mathrm{~m}$. The mesozooplankton biomass reflected the distribution of Calanus finmarchicus and no diurnal differences were observed. At Stn D (only sampling at night), fishes were caught between 40 and $120 \mathrm{~m}$ while euphausiids were dis- tributed in the whole water column, being more concentrated between 40 and $140 \mathrm{~m}$. Shrimps were absent. Euphausiids' biomass was 20 times higher at the head of the fjord (Stn D) than in the main basin (Stn B) while fishes and mesozooplankton biomass were only 36 and $5 \%$ of the biomasses at Stn B respectively (Table 4 ).

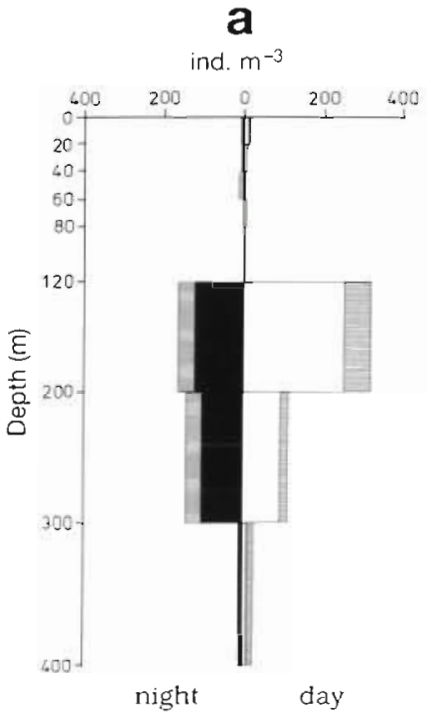

C. finmarchicus

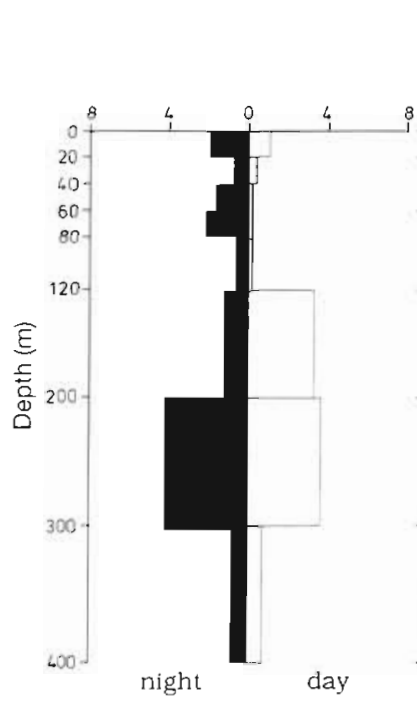

Metridia spp. copcpodites
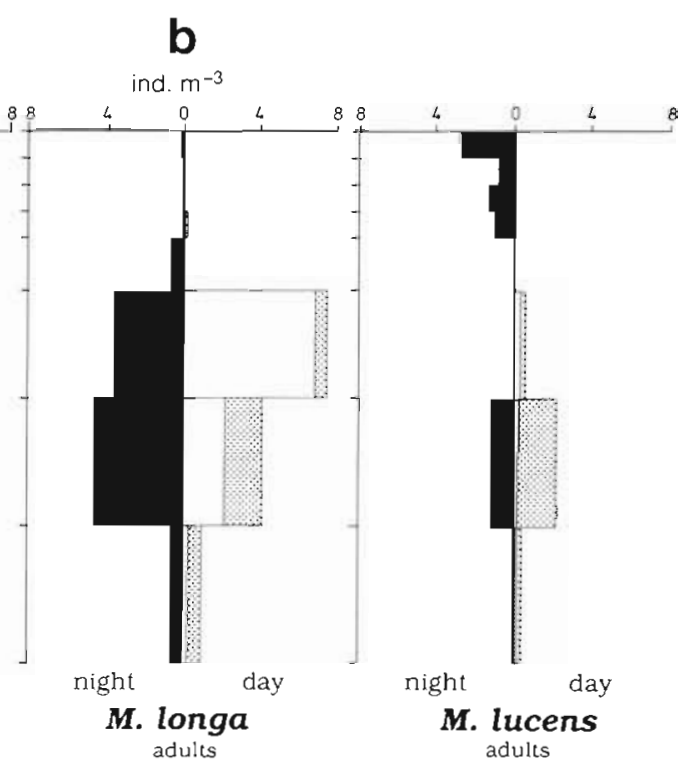

M. Lucens adults

Fig. 11. Copepod abundance and diel vertical distribution of main development stages at Stn B. Average of day ( $\mathrm{n}=2)$ and night $(\mathrm{n}=4$ ) hauls. (a) Calanus finmarchicus. Copepodites $V$, day ( $\square$ ) and night ( $\mathbf{a}$ ); copepodites I to IV+ adults, day (目) and

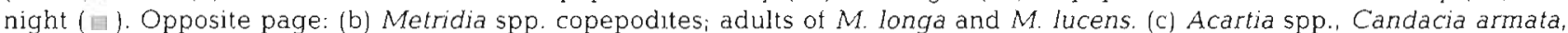
Oithona spp. and Pseudocalanus elongatus. (d) Chiridius armatus and Euchaeta norvegica. Symbols for (b) to (d): Copepodites and females, day ( $\square$ ) and night ( $\mathbf{\square}$ ); males, day (웅 ) and night 


\section{Stomach content analysis}

Benthosema glaciale exhibited a high percentage of empty stomachs (Table 5). Identifiable and unidentifiable digested food was present in similar proportions during the day, while most of the food was digested at night. All identified ingested copepods were calanoids, mainly Calanus. Body size of $B$. glaciale ranged from 13 to $75 \mathrm{~mm}$ in all catches. Two size groups were found (20-25 $\mathrm{mm}$ and 60-65 $\mathrm{mm}$ ), probably corresponding to 2 different age groups.

Two of the four IKMT hauls contained some individuals of Maurolicus muelleri. Almost all stomachs of those caught in the day trawl contained fresh food, with small copepods (Oithona and calanoids) and ostracods dominating the contents. At night the stomachs were either empty or contained digested food (Table 5). The length ranged from 17 to $42 \mathrm{~mm}$.

Most stomachs of Sergestes arcticus were empty or contained digested food. Identifiable food was composed of copepod fragments (i.e. CV Calanus), crustacean appendages and chitinous remains. The maximum percentage of stomachs with contents occurred around sunset. Body length ranged from 32 to $61 \mathrm{~mm}$

The stomach contents of Meganyctiphaes norvegica were dominated by detritus. Remains of crustaceans (ostracods) and digested food were present in a low proportion. The percentage of full stomachs increased from sunset to midnight while most organisms had empty stomachs late at night (Table 5). The range of body length was 14 to $40 \mathrm{~mm}$.
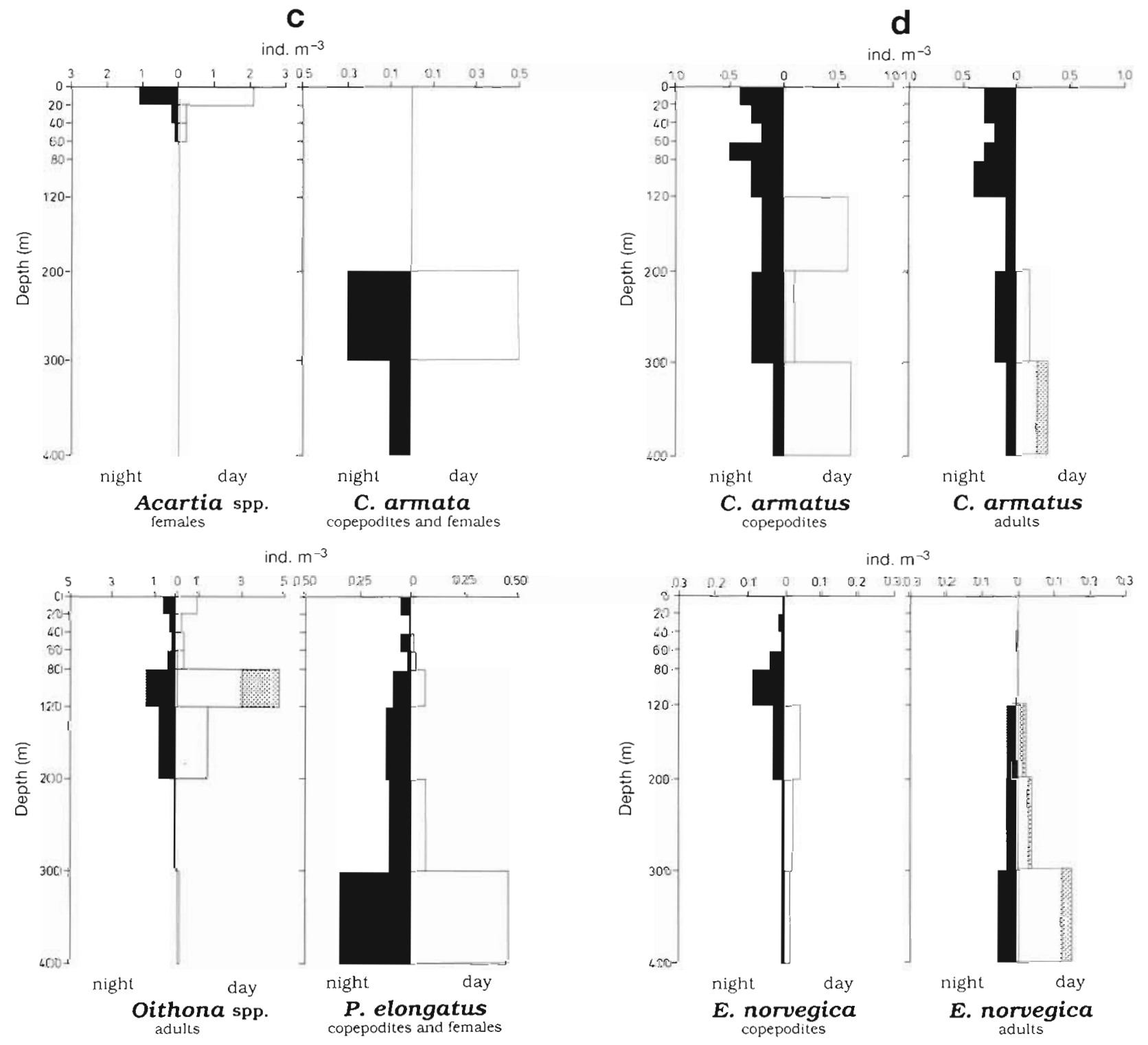

Fig. 11 (continued) 


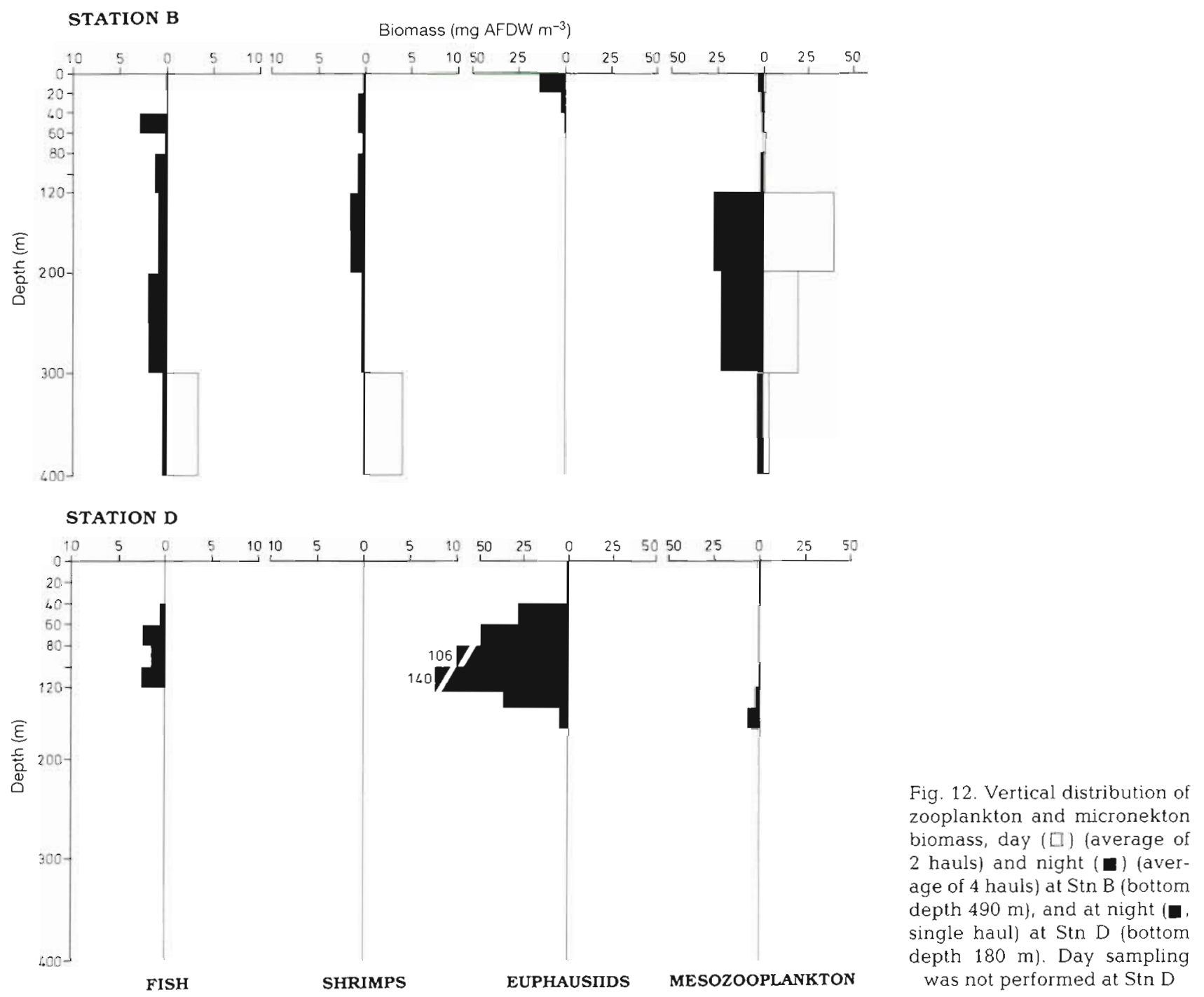

\section{DISCUSSION}

\section{SSLs in Masfjorden in winter}

In the deep basin (Stn B), 2 layers were recorded throughout the study while only a single layer was observed at the head (Stn D) and the entrance to the fjord (Stn A) at night. The number of scattering layers present seemed to be related to the bottom depth, with a second layer present at depths greater than $300 \mathrm{~m}$. The depth effect was also observed at Stn B, when Layer II sometimes disappeared in the vicinity of bottom ridges (Fig. 6). There were also qualitative differences in the scattering. The single layer at Stn A and Layer I at Stn B had similar scattering characteristics and were restricted to a narrow depth at night. On the other hand, the layer at Stn $D$ occupied almost the entire water column and scattering was more intense than in the rest of the fjord. The difference in the number and qualitative characteristics of SSLs present in Masfjorden are due to their different biological composition as will be discussed below.

Table 4. Biomass (mg AFDW $\mathrm{m}^{-2}$ ) of zooplankton and micronekton at Stn B (average of night hauls) and D (single haul at night) from MOCNESS hauls

\begin{tabular}{|lrr|}
\hline Group & \multicolumn{2}{c|}{ Biomass } \\
& Stn B & Str D \\
\hline Fish & 408 & 146 \\
Shrimp & 308 & 0 \\
Euphausiids & 359 & 7382 \\
Mesozooplankton & 5208 & 252 \\
Sum & 6283 & 7780 \\
\hline
\end{tabular}


Table 5. Percentage of stomachs empty and containing food of macroplankton and micronekton from IKMT catches at Stn B. Length $(\mathrm{mm})$ expressed as mean \pm standard deviation, $\mathrm{n}=$ no. of stomachs analyzed

\begin{tabular}{|c|c|c|c|c|c|}
\hline \multirow[t]{3}{*}{ Species } & & \multicolumn{4}{|c|}{ Stomach contents $(\%)$} \\
\hline & & \multicolumn{2}{|c|}{ January 25} & \multicolumn{2}{|c|}{ January 26} \\
\hline & & $13: 47 \mathrm{~h}$ & $15: 05 \mathrm{~h}$ & $00: 38 \mathrm{~h}$ & $03: 49 \mathrm{~h}$ \\
\hline \multirow[t]{4}{*}{ Benthosema glaciale } & $\mathrm{n}$ & 29 & 42 & 47 & 27 \\
\hline & $\%$ Empty & 41 & 69 & 44 & 89 \\
\hline & $\%$ With food & 69 & 31 & 56 & 11 \\
\hline & Length & $42.5 \pm 17.9$ & $51.4 \pm 17.4$ & $36.4 \pm 17.6$ & $30.7 \pm 15.9$ \\
\hline \multirow[t]{4}{*}{ Maurolicus muelleri } & $\mathrm{n}$ & 0 & 3 & 0 & 16 \\
\hline & $\%$ Empty & - & 0 & - & 50 \\
\hline & $\%$ With food & - & 100 & - & 50 \\
\hline & Length & - & $22.0 \pm 1.7$ & - & $23.8 \pm 7.5$ \\
\hline \multirow[t]{4}{*}{ Sergestes arcticus } & $\mathrm{n}$ & 20 & 14 & 7 & 10 \\
\hline & \% Empty & 75 & 43 & 86 & 70 \\
\hline & $\%$ With food & 25 & 57 & 14 & 30 \\
\hline & Length & $41.8 \pm 6.8$ & $46.0 \pm 8.1$ & $44.4 \pm 4.3$ & $43.9 \pm 5.0$ \\
\hline Meganyctiphanes & $\mathrm{n}$ & 0 & 20 & 22 & 30 \\
\hline \multirow[t]{3}{*}{ norvegica } & $\%$ Empty & - & 30 & 9 & 56 \\
\hline & $\%$ With food & - & 70 & 91 & 44 \\
\hline & Length & - & $24.8 \pm 8.0$ & $22.1 \pm 7.4$ & $20.3 \pm 5.0$ \\
\hline
\end{tabular}

High frequency scattering (100 to $120 \mathrm{kHz})$ has usually been associated with krill (Sameoto 1976, 1980, 1982, 1983, Greenlaw 1979, Pieper 1979, Evans \& Hopkins 1981, Simmard et al. 1986, Simard \& Mackas 1989). In Masfjorden, however, a later study using underwater video recordings and pelagic trawls (Giske et al. 1990) revealed that micronektonic fishes were responsible for the SSLs at Stn B. Layer I seemed to be composed by juveniles of Maurolicus muelleri while Layer II was formed mainly by adults of this fish. Giske et al. (1990) concluded that euphausiids were not truly components of the SSLs in the deepest basin of Masfjorden since these organisms were present in the catches of Layer I only at dawn, during their downward migration.

In the present study, the single layer at Stn A and Layer $I$ at Stn B are the same (Fig. 9) and the identity of the SL at the opening of the fjord is thus assigned to juveniles of Maurolicus muelleri. This is in accordance with Kaartvedt et al. (1988) who found only small individuals of this fish at this station. On the other hand, euphausiids were probably the main biological constituents of the single layer at Stn D. This is indicated by the overlapping vertical distribution between the scattering and the krill biomass, which was 20 times larger that at Stn B. Previous studies have shown that large krill biomass and low fish biomass are characteristic of this area (Kaartvedt et al. 1988, authors' unpubl. data).

Because adults of Maurolicus muelleri are restricted to the deepest part of the fjord (Stn B) (Kaartvedt et al. 1988), it is unlikely that Layers I and II 'joined' into a single one in the passage from the main basin to the inner fjord. What the echograms actually show is that Layer I extends into the inner fjord and becomes part of the intense scattering produced by the euphausiids while the extension of Layer II ceases.

The estimated mean ( \pm SD) migrational speeds of the SSLs at Stn B were 19.7 ( \pm 9.1 ) $\mathrm{m} \mathrm{h}^{-1}$ for Layer I and $20.0( \pm 8.0) \mathrm{m} \mathrm{h}^{-1}$ for Layer II, with maximum rates of $90 \mathrm{~m} \mathrm{~h}^{-1}$. These rates are similar to those estimated from SSLs along the northern Norwegian coast (Evans \& Hopkins 1981) where maximum rates always occurred at dusk and dawn. In our study, the highest rates were not only associated with the dusk rise and dawn descent but also observed during the day when large changes of incident radiation occurred due to highly variable cloudiness.

If we assume that an organism react to changes in light intensity, then $z_{1}$ and $z_{2}$ are the organism's depth location before and after the stimulus. The corresponding light at both depths can be calculated as follows:

$$
I_{z_{1}}=I_{0_{1}} \mathrm{e}^{-k z_{1}} \text { and } I_{z_{2}}=I_{0_{2}} \mathrm{e}^{-k z_{2}}
$$

where $I_{z_{i}}=$ light at depth $z_{i} I_{0_{1}}=$ light just below surface at time $i$; and $k=$ extinction coefficient of water (assumed to be constant). Using Eq. (1), the distance swum by the organism as a result of a certain change in light $\left(I_{\mathrm{O}_{1}}-I_{\mathrm{O}_{2}}\right)$ is given by:

$$
z_{1}-z_{2}=-k^{-1} \ln \left(I_{0_{1}} / I_{O_{2}}\right)
$$

which is of the form: $y=b x+a$, where $b=-k^{-1}, a=0$ and $x=\ln \left(I_{0_{1}} / I_{O_{2}}\right)$; that is, the distance travelled is inversely proportional to the extinction coefficient of the water and proportional to the logarithm of the ratio of light before and after the change. The regression 
analysis between the rate of change in surface light and the combined data sets of migrational speed of both SSLs gave a slope coefficient, $b$, of 10.36 (Table 2) which is the same as the average extinction coefficient measured in the upper $60 \mathrm{~m}\left(0.10 \mathrm{~m}^{-1}\right)$ :

$$
b=10.36=k^{-1} \Rightarrow 0.10
$$

Thus, after a change in light, the SSLs would seem to adjust their depth distribution in order to stay at the preferred light intensity (i.e. with an isolume).

Although the upper part of Layer II exhibited high displacement velocities when large changes in surface light occured during day time, even larger light fluctuations at dusk did not affect its migrational speed correspondingly. This layer apparently follows an isolume only to the 'upper limit' of its depth distribution.

In Masfjorden, pre-sunrise ascents of Layer I were observed before light was measurable (Fig. 7). Such displacements have been explained either as a rise to a preferred light level and then descend with it (Blaxter 1976), or as a result from endogenously controlled increase in activity (Rudjakov 1970). Whether this phenomenon is light dependent, indicating a high photosensitivity of the organisms, or due to an increase in activity, is not known.

\section{Horizontal distribution of biomass}

Large differences in the abundance and distribution of the mesopelagic biomass were observed between the main basin ( $\operatorname{Stn} B$ ) and the innermost part of the fjord (Stn D). These differences are probably a consequence of the current system, fjord topography and biological interactions, as suggested by Kaartvedt et al. (1988). The advective processes have been extensively studied in Masfjorden (Kaartvedt 1988, Kaartvedt et al. 1988, Aksnes et al. 1989) and it has been concluded that the advection of zooplankton is an important feature of the fjord ecosystem. The water mass of Masfjorden may be classified as: brackish water (0 to $3 \mathrm{~m})$; intermediate water, found between the brackish water and the sill depth $(75 \mathrm{~m})$; and deep water, found below the sill depth (Aksnes et al. 1989). The transport of brackish water is directed outward and amounts to ca $100 \mathrm{~m}^{3} \mathrm{~s}^{-1}$ (in the sill area). The main transport, however, is found in the intermediate water which may be divided into 2 layers. The water in the upper layer is transported outward (may exceed $1000 \mathrm{~m}^{3} \mathrm{~s}^{-1}$ ) at the onset of northerly winds (upwelling) and inward during southerly winds (downwelling) along the Norwegian coast. The transport in the lower layer is of same magnitude but in the opposite direction. Aksnes et al. (1989) clearly demonstrated that large quantities the of zooplankton are advected in the intermediate layer. Euphausiids seem to be particularly vulnerable to advective transport. The maximum of krill biomass at Stn $D$ indicates active transport from the main basin (and the outer fjord) toward the head of the fjord. This transport takes place, most probably, during night hours when the krill occupy the upper advective layer. The krill at Stn D, on the other hand, is almost confined to the depths below $40 \mathrm{~m}$ and are, thus, retained. The euphausiid distribution in Masfjorden seems, therefore, to be governed by both advective processes and changes in migrational behaviour. Studies on krill on the continental shelf of Vancouver Island (Canada), lead to the same conclusion: advection and migration were responsible for krill aggregation in restricted areas (Simard \& Mackas 1989).

The mesozooplankton is also sensitive to active transport in the upper layers of the deep basin in the summer but not in the winter, where $90 \%$ of the mesozooplankton biomass is located below $120 \mathrm{~m}$ throughout the day and therefore out of the range of horizontal advection. At Stn D, lack of horizontal transport, shallower bottom and high predation pressure by the krill (see below) may explain the large differences in biomass between stations (Table 4).

The biomass and distribution of the micronekton seem to be governed primarily by the topography of the fjord. The shrimps and Benthosema glaciale are deep-living forms and the deep waters of fjords may represent a refuge for resident fjord populations (Kaartvedt 1988). These organisms are also vulnerable to advection, especially the younger stages, although to a lesser extent than the euphausiids. However, they are retained in the main basin by keeping the bulk of the population below the sill depth and thereby away from the advective layers.

\section{Stomach content analysis}

The micronekton had higher feeding activity during light hours. These organisms were apparently food limited as indicated by the high percentage of empty stomachs throughout the study. Krill and copepods are important components of the diet of Benthosema glaciale, Maurolicus muelleri, Sergestes arcticus and Pasiphea multidentata as well (Gjøsæter 1973, Kinzer 1982, Roe 1984, Sameoto 1988). Studies on the seasonal fluctuations in the diet of $B$. glaciale indicate a trend for lower feeding activity towards the colder months (Sameoto 1988), with the highest percentage of empty stomachs during winter (December to February, about $55 \%$ ) (Gjøsæter 1973). Both authors suggested that this is due to scarcity of prey at this time of the year. On the other hand, it is striking that euphausiids were not an important component of the micronekton's diet. 
Common food types of Meganyctiphanes norvegica are copepods, chaetognaths, phytoplankton and detritus (Fisher \& Goldie 1959, Mauchline 1960, 1966). In the present study, $M$. norvegica fed mostly on detritus with increasing feeding activity from sunset to midnight. The average concentration of POC in the water column was about $135 \mathrm{mg} \mathrm{C} \mathrm{m}{ }^{-3}$, which is twice as large as estimates by Giske et al. (1990). POC concentrations in the $20 \mathrm{~m}$ water column of Kiel Bight (Germany) varied between 85 and $204 \mathrm{mg} \mathrm{C} \mathrm{m}^{-3}$ for 2 consecutive Januarys in 1973 and 1974 (Smetacek 1980) while a concentration of $500 \mathrm{mg} \mathrm{C} \mathrm{m}^{-3}$ was measured in the upper $50 \mathrm{~m}$ of Balsfjorden (Norway) in late February (Eilersten 1979). Phytoplankton was practically absent and could not represent a food source at this time of the year. Nothing can be said about the nature of the non-detrital food of the krill due to the high degree of digestion. While krill was not feeding on copepods in the deepest basin, the opposite seemed to be the case at the shallower, innermost part of the fjord (Stn D). Here, a large proportion (>40\%) of the copepods were broken into pieces (mostly Calanus finmarchicus), possibly indicating that these organisms were intensively preyed upon. The depth distribution of these damaged copepods overlapped with the maximum krill biomass. Beyer (1992) claims that the presence of damaged copepods is a consequence of the feeding activity of Meganyctiphanes norvegica.

\section{Why (not) vertical migrations?}

In the diel migration of planktonic and nektonic organisms it is now widely accepted that light is a common stimulus for the vertical displacements, acting as a controlling, initiating and orientating cue during migration (Forward 1988). Recent hypotheses integrate a series of causative factors with the aim of a better interpretation of the ecological advantages of exhibiting or not exhibiting this behaviour (Clark \& Levy 1988, Giske \& Aksnes 1992). It has been suggested that the ratio between mortality risk and feeding rates for organisms that locate their prey by sight, tends to be at a minimum at intermediate levels of light intensities. Thus, migration during dawn and dusk may extend the time available for visual feeding (Clark \& Levy 1988) and in Masfjorden, where the light period is short during winter (about $7 \mathrm{~h}$ ), migration would extend the visual feeding of micronektonic fishes with up to $25 \%$ while minimizing predation risk. If shrimps, krill and the planktivorous polychaete Tomopteris sp. are visual feeders, their diurnal distribution would also be explained by this factor

In addition to predator-avoidance, the dynamics of food utilization and concentration seems to play an important role in shaping migratory behaviour of non-visual feeders, i.e. most zooplankton (Bohrer 1980, Dagg 1985, Conover et al. 1988, Gliwiz \& Pijanowska 1988, Aksnes \& Giske 1990, Leibold 1990, Bollens \& Frost 1991). In Masfjorden, migrant and non-migrant zooplankters were observed, and the advantage of each mode will be discussed in view of factors such as: size, predation risk and trophic level (omnivory vs carnivory).

With the exception of Metridia lucens, the omnivores lacked vertical migration. In waters almost devoid of phytoplankton, these organisms may survive by either hibernating/resting at depth (Calanus finmarchicus, M. longa, Pseudocalanus?), or by exploiting alternative food sources, such as particular organic matter and/or microzooplankton (Acartia, Oithona, M. lucens).

Among carnivores, the differences in their migrating behaviour seemed to be related to their size and the vertical distribution of potential food prey. Chiridius armatus and copepodites of Euchaeta norvegica migrated vertically, probably to survey the water column for organisms of suitable size (i.e. Pseudocalanus, Oithona, Acartia) (Alvarez \& Mathews 1975, Båmstedt \& Holt 1978). On the other hand, the copepods Candacia armata, E. norvegica (adults), and large carnivores such as Aglantha sp. and chaetognaths, remained in deep waters, overlapping with the copepod maximum.

Acknowledgements. We thank J. H. Fossá, S. Kaartvedt and 3 anonymous referees for valuable comments and criticism. We also acknowledge the captain and crew on RV 'Hảkon Mosby' for cooperation and assistance, and Elin Holm for drawing the figures.

\section{LITERATURE CITED}

Aksnes, D. L., Aure J., Kaartvedt S., Magnesen T., Richard J. (1989). Significance of advection for the carrying capacity of fjord populations. Mar. Ecol. Prog. Ser. 50: 263-274

Aksnes, D. L., Giske, J. (1990). Habitat profitability in pelagic environments. Mar. Ecol. Prog. Ser. 64: 209-215

Alvarez, V., Matthews, J. B. L. (1975). Experimental studies on the deep-water community of Korsfjorden, western Norway. Feeding and assimilation by Chiridius armatus (Crustacea, Copepoda). Sarsia 58: 67-78

Bámstedt, U., Holt, M. R. (1978). Experimental studies on the deep-water pelagic community of Korsfjorden, western Norway. Prey-size preference and feeding of Euchaeta norvegica (Copepoda). Sarsia 63: 225-236

Beyer, F. (1992). Meganyctiphanes norvegica (M. Sars) (Euphausiacea), a voracious predator on Calanus, other copepods, and ctenophores, in Oslofjorden, southern Norway. Sarsia 77: 189-206

Blaxter, J. H. S. (1976). The role of light in the vertical migration of fish - a review. In: Evans, G. C., Bainbridge, R., Rackham, O. (eds.) Light as an ecological factor: II. 16th Symp. Brit. Ecol. Soc. 26-28 March 1974, Blackwell Scientific Publications, Oxford, p. 189-210 
Bollens, S. M. Frost, B. W (1991). Diel vertical migration in zooplankton: rapid individual response to predators. J. Plankton Res. 13(6): 1359-1365

Bohrer, R. N. (1980). Experimental studies on diel vertical migration. In: Kerfoot, W. C. (ed.) Evolution and ecology of zooplankton communities. University Press, London, p. $111-121$

Clark, C. W., Levy, D. A. (1988). Diel vertical migrations by juvenile sockeye salmon and the antipredation window Am. Nat. 131(2): 271-290

Conover, R. J., Bedo, A. W., Herman, A. W., Head, E. J. H., Harris, L. R., Horne, E. P. W. (1988). Never trust a copepod - some observations on their behavior in the Canadian arctic. Bull. mar. Sci. 43(3): 650-662

Dagg, M. J. (1985). The effects of food limitation on diel migratory behavior in marine zooplankton. Arch. Hydrobiol. Beih. Ergeb. Limnol. 21: 247-255

Eileresten, H. C. (1979). Planteplankton, minimumsfaktorer og primærproduksjon i Balsfjorden, 1977. Cand. real thesis, Universitet i Tromso

Evans, R. A., Hopkins, C. C. E. \{1981\}. Distribution and standing stock of zooplankton sound-scattering layers along the north Norwegian Coast in February-March 1978. Sarsia 66: $147-160$

Falk-Petersen, S., Hopkins, C. C. E. (1981). Zooplankton sound scattering layers in north Norwegian fjords: interactions between fish and krill shoals in a winter situation in Ullsfjorden and Øksfjorden. Kieler Meeresforsch., Sonderh. 5: 191-201

Falk-Petersen, S., Kristensen, $\AA$. (1985). Acoustic assessment of krill stocks in Ullsfjorden, north Norway. Sarsia 70: 83-90

Farquhar, G. B. (1977). Biological sound scattering in the oceans: a review. In: Andersen, N. R., Zahurance, B. J. (eds.) Oceanic sound scattering prediction. Plenum Press, New York, p. 493-528

Fisher, L. R., Goldie, E. H. (1959). The food of Meganyctiphanes norvegica (M.Sars) with an assessment of the contributions of its components to the vitamin A reserves of the animal. J. mar. biol. Ass. U.K. 38: 291-312

Forward, R. B. (1988). Diel vertical migration: zooplankton photobiology and behaviour. Oceanogr. mar. biol. A. Rev. 26: 361-393

Giske, J., Aksnes, D. L., Baliño, B. M, Kaartvedt, S., Lie, U., Nordeide, J. T., Salvanes, A. B. V., Wakili, S., Aadnesen, A. (1990). Vertical distribution and trophic interactions of zooplankton and fish in Masfjorden, Norway. Sarsia 75: 65-81

Giske, J, Aksnes, D. L. (1992). Ontogeny, season and tradeoffs: vertical distribution of the mesopelagic fish Maurolicus muelleri. Sarsia 77: 253-261

Gjøsæter, J. (1973). The food of the myctophid fish, Benthosema glaciale (Reinhardt) from western Norway. Sarsia 52: $53-58$

Gliwicz, M. Z., Pijanowska, J. (1988). Effect of predation and resource depth distribution on vertical migration of zooplankton. Bull. mar. Sci. 43(3): 696-709

Greenlaw, C. F. (1979). Acoustical estimation of zooplankton populations. Limnol. Oceanogr. 24(2): 226-242

Holm-Hansen, O., Lorenzen, C. J., Holmes, R. W., Strickland, J. D. H. (1965). Fluorometric determinations of chlorophyll J. Cons int. Explor Mer 30: 3-15

Hopkins, C. C. E., Evans, R. A. (1979). Diurnal and horizontal variations in a zooplankton sound scattering layer. In: Naylor, E., Hartmoll, R. (eds.) Cyclic phenomena in marine plants and animals. Proc. 13th Eur. Symp. mar. Biol. Pergamon Press, London, p. 375-382

Kaartvedt, S. (1988). Significance of vertical migrations for advection and retention of fjord-living crustaceans. Dr scient. thesis, University of Bergen

Kaartvedt, S., Aksens, D. L., Aadnesen, A. (1988). Winter distribution of macroplankton and micronekton in Masfjorden, western Norway. Mar. Ecol. Prog. Ser. 45: 45-55

Kinzer, J. (1982). The food of four myctophid fish species off northwest Africa. Rap. P.-v. Réun. Cons. int. Explor. Mer 180: $385-390$

Leibold, M. A. (1990). Resources and predators can affect the vertical distribution of zooplankton. Limnol. Oceanogr. 35(4): $938-944$

Mauchline, J. (1960). The biology of the euphausiid crustacean, Meganyctiphanes norvegica (M. Sars). Proc. R. Soc. Edinb. Sect. B 67-Part II(9): 141-179

Mauchline, J. (1966). The biology of Thysanoessa raschii (M. Sars) with a comparison of its diet with that of Meganyctiphanes norvegica (M. Sars). In: Barnes, H. (ed.) Some contemporary studies in marine science. G. Allen \& Unwin, Ltd, London, p. 493-510

Motoda, S. (1954). Devices of simple plankton apparatus. Mem. Fac. Fish. Hokkaido Univ. 7: 73-94

Pieper, R. E. (1979). Euphausiid distribution and biomass determined acoustically at $102 \mathrm{kHz}$. Deep Sea Res. 26(6A): $687-702$

Reppe, B. (1986). Hydroacoustic assessment and ecology of krill stocks in the inner Oslofjord. Cand. scient. thesis, University of Oslo

Roe, H. S. J. (1984). The diel migrations and distributions within a mesopelagic community in the North East Atlantic. 2. Vertical migrations and feeding of mysids and decapod Crustacea. Prog. Oceanogr. 12: 269-318

Rudjakov, J. A. (1970). The possible causes of diel vertical migration of planktonic animals. Mar. Biol. 6: 98-105

Sameoto, D. D. (1976). Distribution of sound scattering layers caused by euphausiids and their relationship to chlorophyll a concentrations in the Gulf of St. Lawrence Estuary. J. Fish. Res. Bd Can. 33: 681-687

Sameoto, D. D. (1980). Quantitative measurements of euphausids using a $120-\mathrm{kHz}$ sounder and their in situ orientation. Can. J. Fish. Aquat. Sci. 37: 693-702

Sameoto, D. D. (1982). Zooplankton and micronekton abundance in acoustic scattering alyers on the Nova Scotian Slope. Can. J. fish. Aquat. Sci. 39: 760-777

Sameoto, D. D. (1983). Euphausiid distribution in acoustic scattering layers and its significance to surface swarms. J. Plankton Res. 5(2): 129-143

Sameoto, D. D. (1988). Feeding of lantern fish Benthosema glaciale off the Nova Scotial Shelf. Mar Ecol Prog Ser. 44: $113-129$

Simmard, Y., Lacroix, G., Legendre, L. (1986). Diel vertical migrations and nocturnal feeding of a dense coastal krill scattenng layer (Thysanoessa raschi and Meganyctiphanes norvegica) in stratified surface waters. Mar. Biol. $91.93-105$

Simard, Y., Mackas, D. L. (1989). Mesoscale aggregations of euphausiid sound scattering layers on the continental shelf of Vancouver Island. Can. J. Fish. Aquat. Sci 46: $1238-1249$

Smetacek, V.S. (1980). Zooplankton standing stock, copepod faecal peliets and particulate detritus in Kiel Bight. Estuar. coast. mar. Sci. 11: $477-490$

Wiborg, K. F. (1951). The whirling vessel, an apparatus for fractionung of plankton samples. FiskDir. Skr. Ser. Havunders. 9: 1-16

Wiebe, P. H., Morton, A. W., Bradley, A. M., Craddock, J. E., Barber, V., Cowles, T. J., Flierl, G. R. (1985). New developments in the MOCNESS, and apparatus for sampling zooplankton and micronekton. Mar. Biol. 87: 313-323 